\title{
Expression of SI 00A8 correlates with inflammatory lung disease in congenic mice deficient of the cystic fibrosis transmembrane conductance regulator
}

\author{
Sam Tirkos ${ }^{1}$, Susan Newbigging ${ }^{2}$, Van Nguyen ${ }^{1}$, Mary Keet ${ }^{3,4}$, \\ Cameron Ackerley ${ }^{5}$, Geraldine Kent ${ }^{5}$ and Richard F Rozmahel*1,3,4
}

\begin{abstract}
Address: ${ }^{1}$ Department of Pharmacology, University of Toronto, Toronto, Ontario, Canada, ${ }^{2}$ Department of Pathobiology, University of Guelph and Ontario Veterinary College, Guelph, Ontario, Canada, ${ }^{3}$ University of Western Ontario, London, Ontario, Canada, ${ }^{4}$ Lawson Health Research Institute, London, Ontario, Canada and ${ }^{5}$ The Hospital for Sick Children, Toronto, ON, Canada

Email: Sam Tirkos - sam.tirkos@utoronto.ca; Susan Newbigging - snewbigg@uoguelph.ca; Van Nguyen - ttvan.nguyen@utoronto.ca; Mary Keet - mkeet@uwo.ca; Cameron Ackerley - cameron.ackerley@sickkids.on.ca; Geraldine Kent - gkent2@uwo.ca;

Richard F Rozmahel* - rrozmahe@uwo.ca

* Corresponding author
\end{abstract}

Published: 29 March 2006

Respiratory Research2006, 7:51 doi:10.1186/1465-9921-7-51

This article is available from: http://respiratory-research.com/content/7/1/51

(c) 2006Tirkos et al; licensee BioMed Central Ltd.

This is an Open Access article distributed under the terms of the Creative Commons Attribution License (http://creativecommons.org/licenses/by/2.0), which permits unrestricted use, distribution, and reproduction in any medium, provided the original work is properly cited.

\begin{abstract}
Background: Lung disease in cystic fibrosis (CF) patients is dominated by chronic inflammation with an early and inappropriate influx of neutrophils causing airway destruction. Congenic C57BL/ $6 \mathrm{CF}$ mice develop lung inflammatory disease similar to that of patients. In contrast, lungs of congenic BALB/c CF mice remain unaffected. The basis of the neutrophil influx to the airways of CF patients and C57BL/6 mice, and its precipitating factor(s) (spontaneous or infection induced) remains unclear.
\end{abstract}

Methods: The lungs of 20-day old congenic C57BL/6 (before any overt signs of inflammation) and $\mathrm{BALB} / \mathrm{C} C F$ mouse lines maintained in sterile environments were investigated for distinctions in the neutrophil chemokines SI00A8 and SI00A9 by quantitative RT-PCR and RNA in situ hybridization, that were then correlated to neutrophil numbers.

Results: The lungs of C57BL/6 CF mice had spontaneous and significant elevation of both neutrophil chemokines SI00A8 and SI00A9 and a corresponding increase in neutrophils, in the absence of detectable pathogens. In contrast, BALB/c CF mouse lungs maintained under identical conditions, had similar elevations of SI00A9 expression and resident neutrophil numbers, but diverged in having normal levels of SI00A8.

Conclusion: The results indicate early and spontaneous lung inflammation in CF mice, whose progression corresponds to increased expression of both SI00A8 and SI00A9, but not SI00A9 alone. Moreover, since both $\mathrm{C} 57 \mathrm{BL} / 6$ and $\mathrm{BALB} / \mathrm{C}$ CF lungs were maintained under identical conditions and had similar elevations in SI00A9 and neutrophils, the higher SI00A8 expression in the former (or suppression in latter) is a result of secondary genetic influences rather than environment or differential infection. 


\section{Background}

Cystic fibrosis (CF) is an autosomal recessive disease caused by mutations in the Cystic Fibrosis Transmembrane conductance Regulator (CFTR) gene $[1,2]$. Clinical manifestations of CF include exocrine pancreatic insufficiency, intestinal obstruction, male infertility and particularly lung disease [3]. To date, over $1000 \mathrm{CF}$-causative mutations have been identified in CFTR [4].

Lung disease is the leading cause of morbidity and mortality among CF patients, and is increasingly regarded as multifactorial, being a combination of abnormalities in inflammatory response and pathogen clearance, in addition to electrolyte transport and airway surface layer composition [3,5-16]. Due to yet unknown CFTR-dependent processes, CF lung disease presents as a vicious cycle of inflammation and infection, ultimately leading to the destruction of the airways (reviewed in $[3,7,17]$ ). A hallmark of the CF lung disease is a massive and inappropriate influx of neutrophils that release profuse amounts of proteases and activated oxygen radicals, resulting in severe pulmonary damage (reviewed in $[3,7,17]$ ). Along with the inappropriate influx of neutrophil into the CF airways, a dysregulation in the levels of inflammatory cytokines, including IL-1 $\beta$, IL-6, IL- 8 and TNF- $\alpha$ are detected [10-16], [18-20]. Given that numerous studies have demonstrated heightened or prolonged inflammatory responses [5] and upregulation of inflammatory mediators in presymptomatic or uninfected CF infants $[6,8,9,21,22]$, it remains unclear whether the inflammation precedes infection or is a result of its destructive properties.

Mouse models of cystic fibrosis, containing disruptions of the CFTR gene, show epithelial bioelectric lesions similar to that observed in CF patients [23,24](reviewed in [25]). CF mice also manifest different abnormalities of lung physiology and certain strains, including those congenic for C57BL/6, have been shown to be hypersusceptible to infections with CF-associated pathogens and development of inflammatory disease [26-36], also reviewed in [37]. In addition, lungs of CF mice have been shown to demonstrate altered expression profiles of numerous inflammatory markers [31,38-41], reminiscent of the disease in CF patients. Thus, CF mouse models could thus provide important insight into the pathogenesis and/or pathophysiology of the lung disease in patients.

Previous studies by us and others have described a congenic C57BL/6J CF mouse model (B6-CF) that manifests an inflammatory lung phenotype $[26,27,42]$ to some extent similar to that seen in CF patients. The major pulmonary disease phenotype of these mice presents at roughly 6 months-of-age with inflammation, interstitial fibrosis, loss of non-ciliated cells, bronchiolar mucus retention, alveolar wall thickening and alveolar hyperin- flation. At roughly 4 to 5 weeks-of-age B6-CF lungs present a marked influx of neutrophils, which heralds the more advanced inflammatory lesions. This overt lung disease phenotype appears spontaneous in that no precipitating airway pathogen infections are detected either preceding or concurrent to the onset of inflammation. In contrast to the B6-CF animals, congenic BALB/C CF mice (Bc-CF) do not develop any obvious lung disease phenotype, even at later ages [26,27,42].

To gain further insight into the early pathogenesis of the lung disease in B6-CF mice we previously undertook a study to identify genes having differential expression between 20 day-old lungs (before any indications of an abnormal lung phenotype) of B6-CF and age- and sexmatched wild-type sibs maintained in a specific pathogen free environment and free of any detectable lung infection, using Affymetrix GeneChip ${ }^{\mathrm{TM}}$ analysis [43]. These studies identified the neutrophil chemokine S100A8 (also known as mMRP8, Calgranulin B or CP-10) (reviewed in [44]) as having roughly 3-fold elevated expression in the B6-CF compared to wild-type lungs [43]. S100A8, along with the related S100A9 (also known as MRP14), are members of the S100 calcium-binding protein family involved in regulation of calcium dependent intracellular processes (reviewed in [45]) and act as potent chemokines for neutrophil recruitment to sites of inflammation (reviewed in $[44,46,47]$ ). In inflammatory states, expression of S100A8 is co-upregulated with S100A9 $[46,48]$ and reviewed in $[44,47,49-51]$. Here we report that S100A9 expression shows spontaneous (without detectable infection) and early (before 20 days of age) increased expression in lung neutrophils of both B6-CF and Bc-CF mice, in agreement with an approximate 3-fold increase in the number of resident neutrophils. However, the expression of S100A8 was not elevated in the lungs of Bc-CF mice, whereas those of B6-CF showed elevated expression that appeared to correlate with increased neutrophil numbers. Importantly, no increased levels of either S100A8 or S100A9 were detected in other CF-affected tissue (ileum and liver) of these animals. These results suggest: 1) an early and spontaneous (without any detectable precipitating infection) inflammatory phenotype in the lungs of CF mice, 2) progression to overt lung disease in CF mice corresponds to elevated levels of both S100A8 and S100A9 (or only S100A8), but not S100A9 alone, and 3) a prominent influence of secondary genetic factors on differential regulation of S100A8 expression.

\section{Methods \\ Mouse studies}

The B6-CF and Bc-CF mice used for this study and their phenotypes have been described in detail elsewhere $[26,27,52,53]$. All studies were carried out on 20-day-old mice before any evidence of lung inflammation in the B6- 
CF animals as previously described [26,27], and personal communication (Dr. G. Kent). To alleviate the severe intestinal lesions resulting in the early death of the congenic B6-CF mice, they were placed on a liquid Peptamen diet from age 18-days until sacrifice, as previously described [54].

Genomic DNA was prepared from tail clips using a salting-out extraction procedure [55]. Briefly, about $2 \mathrm{~cm}$ of tail was removed and digested overnight at $55^{\circ} \mathrm{C}$ with proteinase $\mathrm{K}(0.5 \mathrm{mg} / \mathrm{ml})$. Proteins were then precipitated with a saturated $\mathrm{NaCl}$ solution followed by centrifugation at 13,000 rpm for $10 \mathrm{~min}$. DNA was ethanol precipitated and redissolved in Tris-EDTA buffer. PCR reactions were performed as previously described [54]. Briefly, the wildtype and mutant CFTR alleles were detected in the mice by PCR, using primers specific for the endogenous CFTR locus and for the mutant CFTR locus: Primer A (wild type) 5'-CTGTAGTTGGCAagCTTTGAC-3'; Primer A (mutant) 5'-ACACTGCTCGAGGGCTAGCCTCTTC-3'; Primer B (wild type and mutant) 5'-CAGTGAAGCTGAGACTGTGAGCTT-3'. The PCR was performed using standardized conditions: $2 \mathrm{mM} \mathrm{MgCl}{ }^{2}, 200 \mathrm{mM}$ dNTPs, $100 \mathrm{nM}$ each primer, 100 ng genomic DNA, and 1 U Taq polymerase. Thermal cycling was carried out for 35 cycles $(1 \mathrm{~min}$, $94^{\circ} \mathrm{C}$; $1 \mathrm{~min}, 50^{\circ} \mathrm{C} ; 1 \mathrm{~min}, 72^{\circ} \mathrm{C}$ ). After electrophoresis the PCR products were visualized on an ethidium bromide stained $1 \%$ agarose gel.

All mice (CF and wild-type controls) were maintained under stringent Specific Pathogen Free (SPF) conditions in microisolator cages at the Hospital for Sick Children Animal Facility, as previously described [26]. Detailed serological surveillance was continuously performed on the entire colony of CF mice using sentinel animals. Sentinels were placed in open cages adjacent to, and/or in the same cage as, the CF heterozygous breeders for 3 months and then exsanguinated. The sera from these animals was frozen and shipped to the University of Missouri Research Animal Diagnostics Laboratory (Columbia, MO) to be screened for rodent viral pathogens (mouse hepatitis, Sendai, mouse pneumonia, respiratory enteric orphan, ectromelia, Theiler's murine encephalitis, mouse adenoviruses 1 and 2, lymphocytic choriomeningitis, infant mouse enzootic diarrhea, polyoma, and parvovirus), Carbacillus and Mycoplasma pulmonis. A second group of sentinels (congenic C57BL/6J CF and C57BL/6J heterozygous CF breeders) housed in open cages adjacent to the heterozygous CF breeders were maintained under the same conditions for an additional 6 weeks. Half of these animals were screened as above, while the remaining mice were sent to the Ontario Veterinary College Department of Pathology, University of Guelph (Guelph, Ontario, Canada) for detailed histopathological screening for signs of infections of their lungs, kidneys, heart, spleen, pancreas, salivary glands, jejunum, ileum, colon, brain, seminal vesicles, thymus, and lymph nodes. Lung and jejunal tissue were also routinely cultured for bacteria, and found to be negative for conventional CF lung pathogens (E. coli, P. aeruginosa, B. cepacia, S. aureus, as well as Proteus and Streptococcus sp). In addition, histopathological screens were also performed to detect pathogenic infections of the specific lung samples used for RNA preparation. The studies performed did not identify any obvious signs of lung infection in the CF animals; nevertheless it is not possible to completely rule out the presence of any undetected pathogens.

\section{mRNA quantification}

Total cellular RNA was extracted from snap-frozen whole right lung lobes dissected from 20-day old CF and wildtype sibs from both the C57BL/6 and BALB/c strains (8 of each genotype/strain) using the Qiagen RNAeasy ${ }^{\mathrm{TM}}$ Midi kit according to the manufacturer's protocol. Sample concentration and purity were determined by measuring optical density at $260 \mathrm{~nm}$ and the ratio of $260 \mathrm{~nm}$ to $280 \mathrm{~nm}$, respectively. A ratio of absorbance $\left(\mathrm{A}_{260} / \mathrm{A}_{280}\right)$ between 1.6 and 1.9 was considered acceptable for purity. RNA integrity was assessed by visualization on an ethidium bromide stained $1 \%$ agarose gel. One microgram of total cellular RNA from each sample was then treated with 1 unit of amplification grade DNase I (Invitrogen) according to the manufacturer's protocol.

To determine S100A8 and S100A9 mRNA expression levels, $1 \mu \mathrm{g}$ of DNase I-treated total cellular RNA from the mouse whole lung was reverse transcribed using the Invitrogen Superscript ${ }^{\mathrm{TM}}$ II RNase H- Reverse Transcriptase FirstStrand Synthesis kit using conditions recommended by the manufacturer. Briefly, $1 \mu \mathrm{g}$ of DNase I-treated total RNA and oligo $(\mathrm{dT})_{12-18}$ primer were incubated at $65^{\circ} \mathrm{C}$ for 5 minutes, added to $5 \mathrm{X}$ RT buffer, $0.1 \mathrm{M} \mathrm{DTT}, 10 \mathrm{mM}$ deoxyribose nucleotide triphosphate (dNTP) mix and incubated at $42^{\circ} \mathrm{C}$ for 2 minutes. Fifty units of Superscript $^{\mathrm{TM}}$ II reverse transcriptase was added and the mixture was incubated at $42^{\circ} \mathrm{C}$ for 50 minutes, $70^{\circ} \mathrm{C}$ for $15 \mathrm{~min}$ utes, then treated with 2 units of RNase $\mathrm{H}$ at $37^{\circ} \mathrm{C}$ for 20 minutes and stored at $-20^{\circ} \mathrm{C}$. Oligonucleotide primers to amplify the target S100A8, S100A9 and the $\beta$-actin CDNA sequences were designed from published cDNA sequences (Genbank ascension numbers S57123, $\underline{\mathrm{M} 83219}$ and $\underline{\mathrm{X} 03672}$, respectively). The primers were chosen to span at least 1 intron to distinguish products resulting from the amplification of cDNA and potentially contaminating genomic DNA. Primer sequences were as follows: S100A8 sense 5'-CCCGTCTTCAAGACATCGTTTG-3' (position 1-22 in the cDNA), S100A8 antisense 5'-ATATCCAGGGACCCAGCCCTAG-3' (position 347-326 in the CDNA), S100A9 sense 5'-CCCTGACACCCTGAGCAAGAAG-3' (position 120-141 in the 
cDNA), S100A9 antisense 5'-TTTCCCAGAACAAAGGCCATTGAG-3' (position 453-430 in the cDNA), $\beta$-actin sense 5'-GTGGGCCGCCCTAGGCACCAG-3' (position $183-203$ in the cDNA), $\beta$-actin antisense 5 -CTCTTTGATGTCACGCACGATTTC-3' (position 722-699). The expected size of the PCR products was 347 bp for S100A8, 333 bp for S100A9 and 539 bp for $\beta$-actin. Multiplex PCR amplification was performed using $1 / 20$ of the total cDNA reverse transcribed from each sample. A total reaction volume of $20 \mu \mathrm{L}$ also contained $200 \mu \mathrm{M}$ dNTP mix, $150 \mu \mathrm{M} \mathrm{MgCl}_{2}, 10 \mathrm{mM}$ Tris-HCl (pH 8.3), $50 \mathrm{mM} \mathrm{KCl}$, 2.5 units of Thermus aquaticus (Taq) DNA polymerase (Fermentas) and $2.5 \mathrm{ng} / \mu \mathrm{L}$ of both sense and antisense oligonucleotide primers for the target (either S100A8 or S100A9) and the endogenous standard ( $\beta$-actin). Four reactions were run in parallel for each sample in a Perkin Elmer Applied Biosystems Geneamp Thermocycler 9700, using a hot-start protocol where Taq polymerase was added to reaction mixtures after an initial denaturation step at $94^{\circ} \mathrm{C}$ for 3 minutes. The reactions were cycled at $94^{\circ} \mathrm{C}$ for 30 seconds (denaturation), $65^{\circ} \mathrm{C}$ for 30 seconds (annealing) and $72^{\circ} \mathrm{C}$ for 30 seconds (extension). Equal volumes of the PCR reaction were removed at cycles 19 , 21, 23 and 25. Fifteen microliters from each PCR reaction were loaded unto an ethidium bromide stained 1\% agarose gel and documented with a Kodak EDAS 290 electrophoresis documentation system. Band intensities (and thus starting product levels) of the target relative to control were measured using the program NIH Image ${ }^{\circledast}$ http:// rsb.info.nih.gov/nih-image/. Band intensities of PCR products (S100A8, S100A9 and $\beta$-actin) were plotted against cycle number in order to determine the exponential phase of amplification. For each sample, the S100A8 and S100A9 multiplex RT-PCR product band intensities after 21 cycles of amplification were normalized to that of the $\beta$-actin produced in the same tube and the mean of the four runs was calculated to obtain relative expression levels. All measurements for expression were performed with the investigator blinded to mouse strain and genotype.

\section{Neutrophil counts}

To ascertain relative neutrophils numbers in the lungs of the different mice (B6-CF, Bc-CF, and their wild-type sibs) the left lung lobes of 7 animals of each strain and genotype were harvested, inflated, and infused with $10 \%$ buffered formalin. After overnight fixation in formalin the lobes were cut into 4 separate sections (from top to bottom of the lobe to maximize representation of the specimen), embedded in paraffin blocks and sectioned to a thickness of $4 \mu \mathrm{m}$ followed by Hematoxylin \& Eosin (H\&E) staining for visual inspection and counts of neutrophils (recognized by their characteristic multi-lobed nuclei) by an experienced pathologist blinded to strain, genotype and expression status. For each of the 4 lung sections from each animal, the number of neutrophils in 6 distinct and randomly chosen fields was counted and the average of the 6 was calculated for that lung section. Thus, a total of 24 distinct sections of each lung from 7 mice (168 total independent fields) of each genotype and strain were counted to arrive at a representative measure of neutrophil content for each group of animals.

\section{RNA in situ hybridization}

Left lung lobes (4 of each genotype/strain) were inflated, fixed in paraformaldehyde, OCT-embedded and thinsliced ( 5 independent sections for each lung) onto aminoalkylsilane-coated slides (SIGMA) followed by air-drying for 2 hrs. Samples were fixed in 4\% paraformaldehyde in PBS for $20 \mathrm{~min}$, protein hydrolyzed in $20 \mu \mathrm{g} / \mathrm{ml}$ proteinase $\mathrm{K}$ for $7.5 \mathrm{~min}$, and then post-fixed for $5 \mathrm{~min}$ in $4 \%$ paraformaldehyde in PBS. Tissues were incubated for 10 min in a $0.1 \mathrm{M}$ triethanolamine, $0.5 \%$ acetic anhydride solution. To dehydrate samples, slides were dipped successively in a graded series of ethanol baths before hybridization. Samples were hybridized overnight at $55^{\circ} \mathrm{C}$ in $50 \%$ formamide, $0.3 \mathrm{M} \mathrm{NaCl}, 20 \mathrm{mM}$ Tris-HCL (pH 7.6), $5 \mathrm{mM}$ EDTA, $10 \%$ dextran sulphate, $1.5 \times$ Denhardts, 0.5 $\mathrm{mg} / \mathrm{ml}$ yeast tRNA, and digoxigenin-UTP-labeled RNA probes. Antisense and sense probes were prepared by in vitro transcription, using T7 RNA polymerase, from a 347 bp sequence (nucleotides 1-347) of S100A8, and a 333 bp sequence (nucleotides 120-453) of S100A9, of HindIII linearized pCR2.1 (Invitrogen) vector with S100A8 and S100A9 inserted in both orientations into the BamHI/HindIII sites of the multiple cloning region. Following hybridization, slides were soaked for $15 \mathrm{~min}$ in 0.1 $\mathrm{M}$ maleic acid and $0.15 \mathrm{M} \mathrm{NaCl}$, then for $1 \mathrm{hr}$ in a $1 \%$ Boehringer blocking reagent solution in $0.1 \mathrm{M}$ maleic acid and $0.15 \mathrm{M} \mathrm{NaCl}$. Bound probes were detected by exposing samples to alkaline phosphatase-conjugated anti-digoxigenin antibodies for $1.5 \mathrm{hrs}$ and slides were then washed in $0.1 \mathrm{M}$ Tris ( $\mathrm{pH}$ 9.5), $0.1 \mathrm{M} \mathrm{NaCl}, 50 \mathrm{mM} \mathrm{MgCl}_{2}$ for $10 \mathrm{~min}$. The substrate, nitro blue tetrazolium/5bromo-4-chloro-3-inolyl phosphate (Invitrogen), was added to the samples and the color reaction was allowed to develop overnight. All samples were hybridized to both anti-sense and sense (negative control) probes to ensure specific signal detection. The number of positive-staining neutrophils in 5 independent fields for each section was counted and the average taken as representative of that lung.

\section{Statistical analysis}

All statistical comparisons were performed using non-parametric Mann-Whitney Tests (2-tailed) and Spearman Rank Correlation tests, as appropriate. Data is plotted as the median with interquartile ranges. 

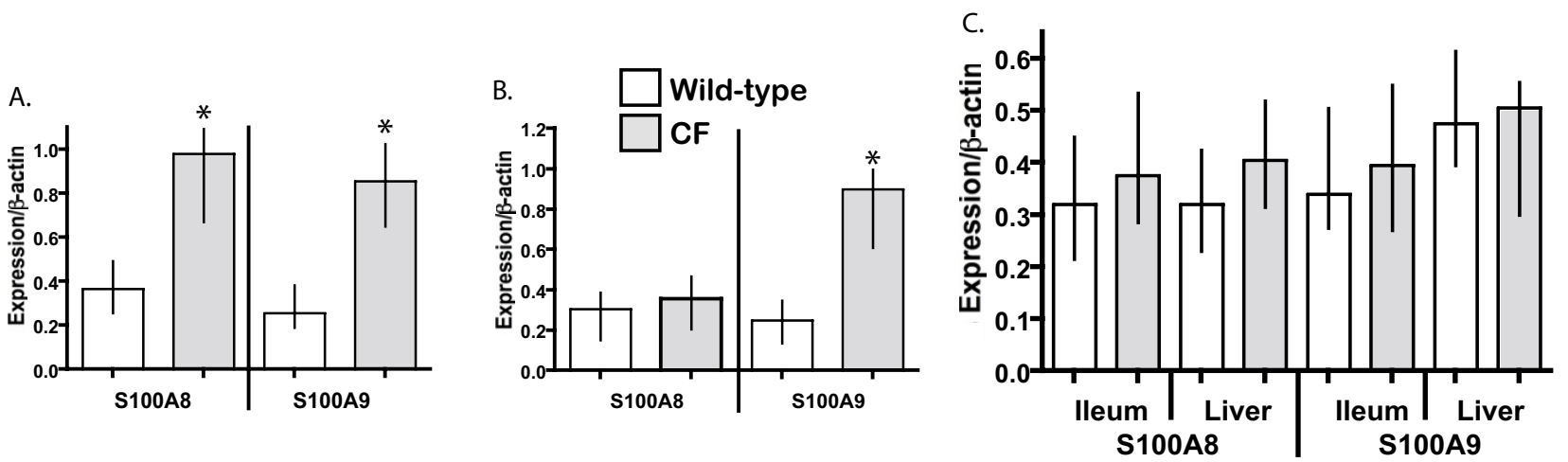

\section{Figure I}

Semi-quantitative reverse-transcriptase PCR of SI00A8 and SI00A9 expression relative to $\beta$-actin in the lungs of $\mathbf{A}$. congenic C57BL/6 CF and wild-type mice, B. congenic BALB/c CF and wild-type mice, ( $n=8$ for each strain/genotype), and C. ileum and liver of CF and wild-type mice from both strains $(n=5$ for each strain/genotype). White and gray bars represent wild-type and CF samples, respectively. Median with $25 \%$ and $75 \%$ intervals are shown. An asterisk (*) denotes a significant difference between the wild-type and CF samples $(p \leq 0.05)$.

\section{Results}

Lung-specific upregulation of SI00A8 and SIO0A9 in CF mice

We had previously reported a roughly 2.5 -fold elevation of S100A8 expression in the lungs of 20 day-old B6-CF mice, as ascertained through an Affymetrix GeneChip experiment [43]. To confirm this increase in expression, semi-quantitative RT-PCR experiments were undertaken. As shown in Fig. 1A, analysis of the expression data showed significantly ( $\mathrm{p} \leq 0.005$, two-tailed Mann-Whitney test) elevated expression of S100A8 ( 2.5-fold) in the lungs of B6-CF mice compared to their wild-type sibs, in agreement with the microarray data. Since the expression of S100A8 may be coordinately regulated with its heterodimerization partner S100A9, the expression level of S100A9 was next investigated in these lungs. As shown in Fig. 1A, expression of S100A9 also had roughly 2.5-fold higher expression in the lungs of B6-CF mice compared to their wild-type littermates ( $\mathrm{p} \leq 0.005)$, confirming a coordinate increase in levels of the two $\mathrm{S} 100$ mRNAs in B6-CF lungs. In contrast, similar studies of 20 day-old Bc-CF lungs, which do not progress to the inflammatory lung disease phenotype, maintained under identical conditions showed no significant increase in S100A8 expression ( $\mathrm{p} \leq 0.5)$, although expression of S100A9 was significantly elevated $(\mathrm{p} \leq 0.001)$ in a manner similar to that of the B6-CF samples (Fig. 1B). A significant increase of S100A8 levels was detected in all 8 B6-CF lungs examined, while none of the B6-WT, Bc-CF or Bc-WT lung samples from identical environments showed a marked elevation. Furthermore, no significant difference in either S100A8 or S100A9 expression levels was detected in nonairway tissue, including the ileum (tissue most severely affected in CF mice) or liver of CF compared to wild-type animals of both $\mathrm{C} 57 \mathrm{BL} / 6 \mathrm{~J}$ and BALB/cJ strains ( $\leq 50.5$, five mice for each group), as shown in Fig. 1C, indicating that increased levels of S100A8 and S100A9 expression were lung specific.

These results indicate an early and specific increase of both S100A8 and S100A9 expression levels in lungs of B6CF mice in contrast to Bc-CF lungs in which only S100A9 expression levels were elevated.

\section{Elevated neutrophils in CF mouse lungs}

To assess the basis of the differential S100A8 and S100A9 levels, the number of resident neutrophils (primary sites of S100A8 and S100A9 expression) between the lungs of 20 day-old B6-CF, Bc-CF and their wild-type sibs were next quantified as described in Materials and Methods. As shown in Fig. 2, the B6-CF mice showed a significant 2.6fold increase in resident neutrophils in their airways and interstitium, compared to their wild-type sibs $(\mathrm{p} \leq 0.001)$. Similarly, Bc-CF mice had a significant roughly 3 -fold increase in neutrophil numbers compared to their wildtype sibs ( $\mathrm{p} \leq 0.005)$. Thus, since neutrophils are the primary site of expression of S100A 8 and S100A9, and the B6-CF and Bc-CF lungs showed an almost 3-fold increase in neutrophil count, respectively, the elevation of S100A9 in both strains of CF lungs, and in the B6-CF lungs for S100A8, likely corresponds to the increased neutrophil numbers. Supplementary assessment of the correspondence between neutrophil numbers and S100A8/S100A9 expression levels per sample was performed by Spearman Rank Correlation analyses, which further supported a likely relationship ( $\mathrm{p} \leq 0.005$ for all results, with the 


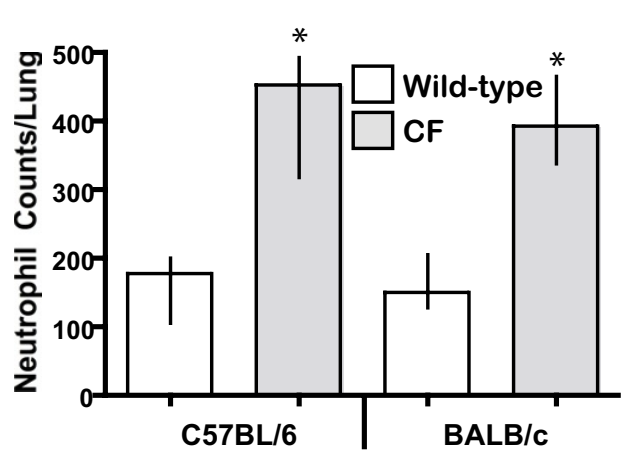

Figure 2

Neutrophil counts. The average number of neutrophils in the lungs of 20 day-old congenic C57BL/6 and BALB/c wild-type (white bars) and CF (gray bars). The average number of neutrophils per lung section ( $n=4$ levels per left lobe, $n=6$ fields for each level) from 7 animals per strain/genotype is represented. Median with $25 \%$ and $75 \%$ intervals are shown. An asterisk $(*)$ denotes a significant difference between the wild-type and CF samples $(p \leq 0.05)$.

exception of S100A8 in the Bc-CF lungs ( $\mathrm{p} \leq 0.5)$ ). The lack of correlation between S100A8 levels and neutrophil numbers in the $\mathrm{Bc}-\mathrm{CF}$ lungs suggests a suppression of its expression in neutrophils in this strain. An assessment of resident macrophage between the $\mathrm{B} 6-\mathrm{CF}$ and $\mathrm{B} 6-\mathrm{WT}$ lungs did not detect a significant difference in numbers (data not shown), suggesting that this early course of the inflammatory lung phenotype appears to be limited to neutrophils.

\section{Localization of SIOOA8 and SI00A9 lung expression}

To confirm the specific cell types conferring S100A8 and S100A9 expression, RNA in situ hybridization of lung sections taken from 20-day old Bc-CF, B6-CF mice and their wild-type sibs was performed. As expected, hybridization of the lung sections with S100A8 and S100A9 sense probes showed no positively staining cells (Fig. 3A and 3F, respectively). Both the S100A8 and S100A9 antisense probes detected staining only in a small number of scattered neutrophils in the B6-WT lungs (Fig. 3D and I, respectively), which did not appear significantly different in number to that seen in the Bc-WT lungs (Fig. 3B and $3 \mathrm{G}$, respectively). Hybridization of Bc-CF lung sections with S100A8 (Fig. 3C) only rarely detected positively staining cells, similar to their Bc-WT sibs, whereas S100A9 (Fig. 3H) detected markedly more staining cells, which were identified morphologically as neutrophils. In contrast, both the S100A8 and S100A9 probes detected significantly higher numbers of positive neutrophils in the B6CF lungs (Fig. 3E and 3J, respectively). Summation of the number of total S100A8 and S100A9 staining neutrophils per B6 lung assessed revealed an almost 3-fold higher number of positive cells in the CF compared to wild-type

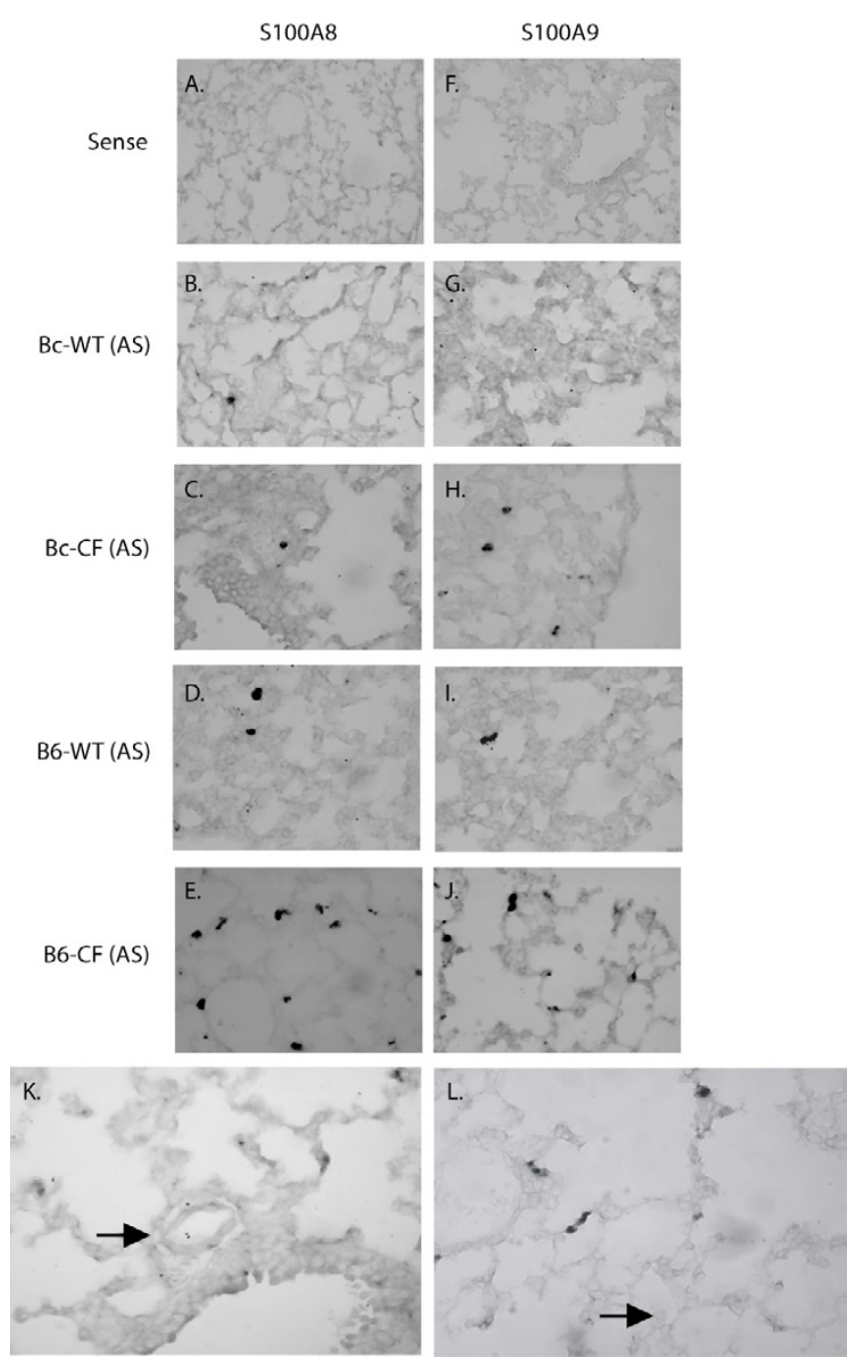

Figure 3

RNA in-situ hybridization of lungs with SI00A8 and SI00A9. Panels $\mathbf{A}$ and $\mathbf{F}$ represent 20 day-old congenic C57BL/6J CF lung sections stained with a sense probe for SI00A8 and SI00A9, respectively. The panels are representative of SI00A8 antisense hybridized sections of 20 day-old Bc-WT (B), Bc-CF (C), B6-WT (D) and B6-CF (E) mouse lungs, and SI00A9 antisense probe hybridized sections of 20 day-old $\mathrm{Bc}-\mathrm{WT}(\mathbf{G}), \mathrm{Bc}-\mathrm{CF}(\mathbf{H}), \mathrm{B} 6-\mathrm{WT}(\mathbf{I})$ and B6-CF (J) mouse lungs. Panels $\mathbf{K}$ and $\mathbf{L}$ show a absence of staining for SI00A8 in endothelial cells and macrophage of 20 day-old B6-CF lungs, respectively. Panels A-J are shown at $40 \mathrm{X}$ magnification and panels $K$ and $L$ are at $60 \times$ magnification.

lungs ( $\mathrm{p} \leq 0.01$, in both cases) (Fig. 4), in agreement with the increased numbers of neutrophils identified by morphometric measures and the increase in levels of expression in the lungs. A similar determination of the number of total S100A8 and S100A9 staining cells in the samples from the Bc strain showed no significant difference $(\mathrm{p} \leq$ 0.20 ) with S100A8; however, the S100A9 probe detected 


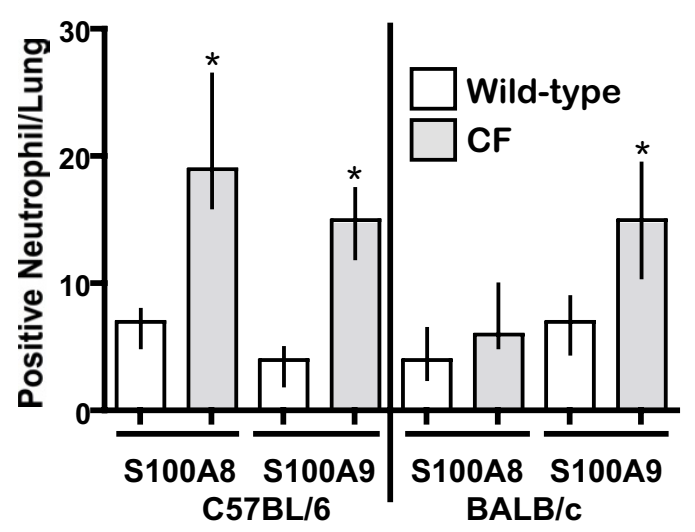

Figure 4

Counts of positively staining neutrophils for SI00A8 (A8) and SI00A9 (A9) in lungs of 20 day-old congenic C57BL/6 and BALB/c wild-type (white bars) and CF (gray bars) mice. The values represent the average number of positive-staining neutrophils from 4 mice of each strain/genotypes with 5 independent sections and 5 fields from each section for each. Median with $25 \%$ and $75 \%$ intervals are shown. An asterisk (*) denotes a significant difference between the wild-type and CF samples $(P \leq 0.05)$.

a significant $(\mathrm{p} \leq 0.01)$ increase positively-staining neutrophils (Fig. 4), in agreement with the morphometric measures and increased whole lung expression.

Importantly, other cell types reported to have inducible expression (vascular endothelial cells and macrophage) were negative for S100A8 staining in B6-CF lungs (Figure $3 \mathrm{~K}$ and $3 \mathrm{~L}$, respectively), indicating that its increased levels in whole lungs were not the effect of induction in such cells, but exclusively due to the increased numbers of expressing neutrophils. However, due to limitations inherent of RNA in situ hybridization it was not possible to quantitate S100A8/S100A9 expression levels on a per cell level.

\section{Discussion}

Differential disease states between distinct congenic mouse strains harboring identical mutations and maintained in a common environment provides a powerful means for identifying secondary genetic factors that have influence disease phenotypes. Here we report that the lungs of 20-day old congenic C57BL/6J CF mice, that progress to overt inflammatory disease, maintained in a sterile environment have elevated numbers of neutrophils and a corresponding increased level of both S100A8 and S100A9, which is not detected in other CF-affected tissues (ileum and liver). In contrast, the lungs of 20-day old congenic BALB/cJ CF mice, which do not develop any obvious inflammatory phenotype, housed with the congenic
C57BL/6J CF animals, had no increase in S100A8 levels, although resident airway neutrophil numbers and S100A9 levels were similarly elevated.

S100A8 (calgranulin A, MRP8) and S100A9 (calgranulin $\mathrm{B}, \mathrm{MRP} 14$ ) are small cytoplasmic proteins (members of the S100 family of the EF hand calcium-binding proteins [56]) that are expressed principally, constitutively and coordinately by circulating neutrophils and monocytes but not normally in tissue macrophages or lymphocytes [57]. The two proteins make up roughly 30\% of the cytosolic protein in these cells [58] and support distinct functions (both as monomers and homodimers), as well as forming calprotectin (S100A8/S100A9 heterodimer) in the presence of $\mathrm{Ca}^{2+}$, with potentially different function(s). Although an understanding of the complete role(s) of each of S100A8, S100A9 and calprotectin is currently lacking $[57,59]$ diverse functions that could impact on CF lung disease have been attributed to them, including calcium sensing [60], cell differentiation, arachidonic acid metabolism $[61,62]$, as well as leukocyte and monocyte endothelial microvascular adherence, transmigration and retention [63-69]. Moreover, calprotectin is implicated in bacteriostasis (reviewed in $[44-46,51,70]$ ), possibly by sequestering $\mathrm{Zn}^{2+}[71-78]$ as well as inhibiting the adhesion of bacteria to mucosal epithelial cells [79]. S100A8's important role in regulating inflammatory processes is clearly indicated in S100A8-null mice, where loss of immunoprotection from invading maternal cells results in embryonic death shortly after implantation [80].

During chronic inflammatory conditions, including that underlying CF lung disease, S100A8 and S100A9 are coordinately upregulated and secreted into the extracellular milieu $[57,81]$, and their products elevated in the serum of patients [82-87], (reviewed in [50]). Likewise, coordinate regulation of S100A8 and S100A9 is also observed in neutrophils where absence of S100A9 leads to a coordinate loss of S100A8 expression $[60,88]$. However, the concise mechanisms of regulatory controls that underlay S100A8 and S100A9 expression are unclear, although they are known to be complex and involve proinflammatory mediators including lipopolysaccharides [89], TNF, IFN- $\gamma$ and IL-1 $[90,91]$.

The results of the present study are important to further understand the basis and pathogenesis of the inflammatory lung phenotype of CF mice, its distinction among different congenic strains and possibly having implications to understanding airway disease of CF patients. Several important points can be drawn from these results. First, these results provide further support for the increasingly prevalent notion of spontaneous inflammation of the CF airways. This conclusion is supported by: 1) the early inci- 
dence of elevations in S100A8 and S100A9 expression along with resident neutrophil influx, 2) the fact that the mice were maintained in sterile environments without detectable lung pathogens, and 3) elevated S100A8 levels were detected in the B6-CF lungs but not $\mathrm{Bc}-\mathrm{CF}$ airways maintained in identical environments.

Second, since S100A8 and S100A9 act as potent leukocyte chemokines and their elevation at 20-days of age are the earliest reported signs of a lung inflammatory phenotype in CF mice, this elevation may be directly responsible for eliciting the massive neutrophil influx observed in 4-5 week old B6-CF lungs $[26,27,42]$.

Third, these results implicate S100A8 alone or both S100A8/S100A9 (calprotectin), but not S100A9 alone, as having a possible role in progression of the inflammatory lung phenotype in CF mice.

Finally, since both the B6-CF and Bc-CF mice were maintained in identical environments, the differential levels of S100A8 expression between the two strains is likely influenced by secondary genetic factors acting on neutrophils (either intrinsically or through the pulmonary interstitial milieu) to either suppress or upregulate its expression in the $\mathrm{Bc}$ or $\mathrm{B} 6$ strain, respectively, rather than the effect of differential environmental exposures or infection status. However, since the elevated levels of S100A8 in the B6-CF lungs agrees with the corresponding increased population of neutrophils and no expression was detected in inducible cells (endothelial and macrophage), it is more likely that its expression is being suppressed in the Bc strain as opposed to B6-CF, which maintains expression in resident neutrophils. Since S100A8 is normally expressed in circulating but not interstitial neutrophils [58], a possible explanation for the differential S100A8 levels is that B6CF neutrophils do not properly recognize or transition to the resident milieu of the CF lung, or their mechanism of suppression may be compromised; thereby, B6-CF neutrophils fail to properly down-regulate S100A8 expression once they leave circulation and enter the lung interstitium, which may constitute a basic defect of the neutrophils or lung in the absence of CFTR function. In this regard, further studies of differences between the B6-CF and $\mathrm{Bc}-\mathrm{CF}$ lungs in terms of signaling pathways and the mechanisms underlying the neutrophil phenotype transition from circulatory to interstitial, as well as the effect of differential lung milieus on this transition will be required to ascertain the mechanistic basis of this defect.

The results of this study extend on two previous reports of S100A8 overexpression in the lungs of distinct CF mouse lines $[31,38]$. In the first study by Thomas et al. [31], a constitutive 4-fold overexpression of S100A8 was detected in the lungs of CF mice homozygous for the G551D muta- tion (in which a spontaneous lung inflammatory phenotype has not been reported) compared to controls. Although expression of S100A9 was not investigated, the results suggested that $\mathrm{CF}$ pathology relates to abnormal regulation of the immune system. Importantly, however, this report documented significant variations in basal expression of S100A8 between individual G551D CF lungs, and since these mice were of a mixed $129 / \mathrm{Sv} \times \mathrm{CD} 1$ strain the differences was attributed to genetic variations. It is thus possible that the same genetic factor(s) conferring marked differences in S100A8 expression between congenic $\mathrm{C} 57 \mathrm{BL} / 6$ and $\mathrm{BALB} / \mathrm{c}$ CF lungs correspond to those of the former study, and that the consistent overexpression inherent to the congenic lines (as opposed to the variability of the mixed background) are necessary for the clear and consistent detection of a lung inflammatory phenotype. In the study by Xu et al. [38], a series of microarray analyses were performed to identify differential gene responses to the loss of CFTR in the lungs of FVB/N X C57BL/6 mixed background mice. Of the multiple genes identified as having significantly up- or down-regulated expression in the CF lungs, both S100A8 and S100A9 were found to be roughly 2 -fold elevated. However, the specific cells conferring the overexpression and its possible effect on a lung inflammatory phenotype were not investigated. Moreover, since these studies were similarly performed on mixed background mice that would likely also have marked variability in S100A8 and/or S100A9 levels, the potential effect of the overexpression on the lung phenotype could not be readily assessed, in contrast to the strictly controlled aspects of the present investigation.

The results presented here justify additional studies to clarify the role of S100A8 overexpression on the pathogenesis and/or progression of the CF lung inflammatory disease, and, in particular, the possible effect of S100A8 inhibition.

\section{Conclusion}

Taken together, these results derived from geneticallydefined CF mice maintained in strict controlled environments provide further support for an early and spontaneous induction of inflammation in lungs devoid of the cystic fibrosis transmembrane conductance regulator, and suggest that S100A8 may play a prominent role. Moreover, since similar elevations of S100A8/S100A9 are detected in CF patients, these results also provide justification for the application of congenic C57BL/6J CF mice as a potential model to gain insight into the pathogenesis of lung disease of CF patients and potential therapeutic avenues.

\section{Abbreviations}

CF: cystic fibrosis 
CFTR: cystic fibrosis transmembrane conductance regulator

B6-CF: congenic C57BL/6 CF mice

Bc-CF: congenic BALB/c CF mice

\section{Competing interests}

The author(s) declare that they have no competing interests.

\section{Authors' contributions}

ST performed the majority of the studies, particularly the lung dissection, quantitative RT-PCR, RNA in situ hybridization, neutrophil counts and drafting of the manuscript. $\mathrm{SN}$ assisted in morphometric analysis, neutrophil and macrophage counts and lung histopathology. VN assisted in RNA preparation, interpretation of quantitative RTPCR and RNA in situ hybridizations. MK performed mouse colony maintenance and genotyping. CA assisted in lung neutrophil and macrophage analysis, measurements and interpretation. GK provided the mice and pathogen monitoring/status and interpretation. RFR designed and supervised the study, and revised the final manuscript.

\section{Acknowledgements}

The authors wish to acknowledge the professional technical assistance of Ms Iris Fang. These studies were supported by a grant from the Canadian Cystic Fibrosis Foundation to RFR and a National Institutes of Health Research SCOR grant.

\section{References}

I. Rommens JM, lannuzzi MC, Kerem B, Drumm ML, Melmer G, Dean M, Rozmahel R, Cole JL, Kennedy D, Hidaka N, Zsiga M, Buchwald M, Riordan J, Tsui L-C, Collins FS: Identification of the cystic fibrosis gene: chromosome walking and jumping. Science 1989, 245(4922): $1059-1065$.

2. Riordan JR, Rommens J, Kerem B, Alon N, Rozmahel R, Grzelczak Z, Zielenski J, Lok S, Plavsic N, Chou J-L, Drumm M, lannuzzi M, Collins SF, Tsui L-C: Identification of the cystic fibrosis gene: cloning and characterization of complementary DNA. Science 1989, 245(4922): 1066-1073.

3. Welsh MJ, Ramsey BW, Accurso FJ, Cutting GR, (ed): Cystic fibrosis. Eigth edition. New York, NY: McGraw-Hill Inc; 2001.

4. Cystic Fibrosis Mutation Database [http://www.genet.sick kids.on.ca/cgi-bin/WebObjects/MUTATION]

5. Muhlebach MS, Stewart PW, Leigh MW, Noah TL: Quantitation of inflammatory responses to bacteria in young cystic fibrosis and control patients. Am J Respir Crit Care Med 1999, 160(1): $|86-19|$.

6. Konstan MW, Hilliard KA, Norvell TM, Berger M: Bronchoalveolar lavage findings in cystic fibrosis patients with stable, clinically mild lung disease suggest ongoing infection and inflammation. Am J Respir Crit Care Med 1994, I 50(2):448-454.

7. Konstan MW, Berger M: Current understanding of the inflammatory process in cystic fibrosis: onset and etiology. Pediatr Pulmonol 1997, 24(2): I37-I42.

8. Balough K, McCubbin M, Weinberger M, Smits W, Ahrens R, Fick R: The relationship between infection and inflammation in the early stages of lung disease from cystic fibrosis. Pediatr Pulmonol 1995, 20(2):63-70.

9. Khan TZ, Wagener JS, Bost T, Martinez J, Accurso FJ, Riches DW: Early pulmonary inflammation in infants with cystic fibrosis. Am J Respir Crit Care Med 1995, I 5 I(4): 1075- 1082.
10. Bonfield TL, Konstan MW, Berger M: Altered respiratory epithelial cell cytokine production in cystic fibrosis. J Allergy Clin Immunol 1999, 104(I):72-78.

II. Bonfield TL, Konstan MW, Burfeind P, Panuska JR, Hilliard JB, Berger M: Normal bronchial epithelial cells constitutively produce the anti-inflammatory cytokine interleukin- 10 , which is downregulated in cystic fibrosis. Am J Respir Cell Mol Biol 1995, 13(3):257-261.

12. Bonfield TL, Panuska JR, Konstan MW, Hilliard KA, Hilliard JB, Ghnaim H, Berger M: Inflammatory cytokines in cystic fibrosis lungs. Am J Respir Crit Care Med 1995, I 52(6 Pt I):2 I I I-2 II 8.

13. Massengale AR, Quinn FJr, Yankaskas J, Weissman D, McClellan WT, Cuff C, Aronoff SC: Reduced interleukin-8 production by cystic fibrosis airway epithelial cells. Am J Respir Cell Mol Biol 1999, 20(5): $1073-1080$

14. Stecenko AA, King G, Torii K, Breyer RM, Dworski R, Blackwell TS, Christman JW, Brigham KL: Dysregulated cytokine production in human cystic fibrosis bronchial epithelial cells. Inflammation 200I, 25(3): I $45-155$.

15. Tabary O, Zahm JM, Hinnrasky J, Couetil JP, Cornillet P, Guenounou $M$, Gaillard D, Puchelle E, Jacquot J: Selective up-regulation of chemokine IL-8 expression in cystic fibrosis bronchial gland cells in vivo and in vitro. Am J Pathol 1998, I 53(3):92 I-930.

16. Venkatakrishnan A, Stecenko AA, King G, Blackwell TR, Brigham KL, Christman JW, Blackwell TS: Exaggerated activation of nuclear factor-kappaB and altered IkappaB-beta processing in cystic fibrosis bronchial epithelial cells. Am J Respir Cell Mol Biol 2000, 23(3):396-403.

17. Doring G, Worlitzsch D: Inflammation in cystic fibrosis and its management. Paediatr Respir Rev 2000, I (2): I0I- 106.

18. Kammouni W, Figarella C, Marchand S, Merten M: Altered cytokine production by cystic fibrosis tracheal gland serous cells. Infect Immun 1997, 65(12):5 I76-5I83.

19. Kube D, Sontich U, Fletcher D, Davis PB: Proinflammatory cytokine responses to $P$. aeruginosa infection in human airway epithelial cell lines. Am J Physiol Lung Cell Mol Physiol 200I, 280(3):L493-502.

20. Schwiebert LM, Estell K, Propst SM: Chemokine expression in CF epithelia: implications for the role of CFTR in RANTES expression. Am J Physiol 1999, 276(3 Pt I):C700-7IO.

21. Rosenfeld M, Gibson RL, McNamara S, Emerson J, Burns JL, Castile R, Hiatt P, McCoy K, Wilson CB, Inglis A, Smith A, Martin TR, Ramsey $B W$ : Early pulmonary infection, inflammation, and clinical outcomes in infants with cystic fibrosis. Pediatr Pulmonol 200I, 32(5):356-366

22. Armstrong DS, Grimwood K, Carzino R, Carlin JB, Olinsky A, Phelan PD: Lower respiratory infection and inflammation in infants with newly diagnosed cystic fibrosis. Bmj 1995, 3 I0(6994): I57|-I572.

23. Grubb BR, Paradiso AM, Boucher RC: Anomalies in ion transport in CF mouse tracheal epithelium. Am J Physiol 1994.

24. Grubb BR, Vick RN, Boucher RC: Hyperabsorption of $\mathbf{N a}$ and raised $\mathrm{Ca}(2+)$-mediated $\mathrm{Cl}$-secretion in nasal epithelia of $\mathrm{CF}$ mice. Am J Physiol 1994.

25. Scholte BJ, Davidson DJ, Wilke M, De Jonge HR: Animal models of cystic fibrosis. I Cyst Fibros 2004, 3(Suppl 2): $183-190$

26. Kent G, lles R, Bear CE, Huan LJ, Griesenbach U, McKerlie C, Frndova $H$, Ackerley C, Gosselin D, Radzioch D, O'Brodovich H, Tsui LC, Buchwald $M$, Tanswell AK: Lung disease in mice with cystic fibrosis. J Clin Invest 1997, I 00(1 2):3060-3069.

27. Haston CK, McKerlie C, Newbigging S, Corey M, Rozmahel R, Tsui LC: Detection of modifier loci influencing the lung phenotype of cystic fibrosis knockout mice. Mamm Genome 2002, I3(II):605-6I3.

28. Durie PR, Kent G, Phillips MJ, Ackerley CA: Characteristic multiorgan pathology of cystic fibrosis in a long-living cystic fibrosis transmembrane regulator knockout murine model. $\mathrm{Am} J$ Pathol 2004, 164(4): I I8I-I 493.

29. Heeckeren A, Walenga R, Konstan MW, Bonfield T, Davis PB, Ferkol $T$ : Excessive inflammatory response of cystic fibrosis mice to bronchopulmonary infection with Pseudomonas aeruginosa. J Clin Invest 1997, 100 (I I):2810-28I5.

30. Cowley EA, Wang CG, Gosselin D, Radzioch D, Eidelman DH: Mucociliary clearance in cystic fibrosis knockout mice infected with Pseudomonas aeruginosa. Eur Respir J 1997, I0(I0):2312-2318. 
31. Thomas GR, Costelloe EA, Lunn DP, Stacey KJ, Delaney SJ, Passey R, McGlinn EC, McMorran BJ, Ahadizadeh A, Geczy CL, Wainwright BJ, Hume DA: G55 ID cystic fibrosis mice exhibit abnormal regulation of inflammation in lungs and macrophages. J Immunol 2000, 164(7):3870-3877.

32. Davidson DJ, Dorin JR, McLachlan G, Ranaldi V, Lamb D, Doherty C Govan J, Porteous DJ: Lung disease in the cystic fibrosis mouse exposed to bacterial pathogens. Nat Genet I995, 9(4):35I-357.

33. Coleman FT, Mueschenborn S, Meluleni G, Ray C, Carey VJ, Vargas SO, Cannon CL, Ausubel FM, Pier GB: Hypersusceptibility of cystic fibrosis mice to chronic Pseudomonas aeruginosa oropharyngeal colonization and lung infection. Proc Natl Acad Sci U S A 2003, 100(4):1949-1954.

34. McMorran BJ, Palmer JS, Lunn DP, Oceandy D, Costelloe EO, Thomas GR, Hume DA, Wainwright B]: G55 ID CF mice display an abnormal host response and have impaired clearance of Pseudomonas lung disease. Am J Physiol Lung Cell Mol Physiol 200I, 28 I(3):L740-747.

35. Sajjan U, Thanassoulis G, Cherapanov V, Lu A, Sjolin C, Steer B, Wu Y], Rotstein OD, Kent G, McKerlie C, Forstner J, Downey GP: Enhanced susceptibility to pulmonary infection with Burkholderia cepacia in Cftr(-/-) mice. Infect Immun 200I, 69(8):5138-5I50

36. Guilbault C, Martin P, Houle D, Boghdady ML, Guiot MC, Marion D, Radzioch D: Cystic fibrosis lung disease following infection with Pseudomonas aeruginosa in Cftr knockout mice using novel non-invasive direct pulmonary infection technique. $L a b$ Anim 2005, 39(3):336-352.

37. Stotland PK, Radzioch D, Stevenson MM: Mouse models of chronic lung infection with pseudomonas aeruginosa: models for the study of cystic fibrosis. Pediatr Pulmonol 2000, 30(5):413-424.

38. Xu Y, Clark JC, Aronow BJ, Dey CR, Liu C, Wooldridge JL, Whitsett JA: Transcriptional adaptation to cystic fibrosis transmembrane conductance regulator deficiency. J Biol Chem 2003 278(9):7674-7682.

39. Bensalem N, Ventura AP, Vallee B, Lipecka J, Tondelier D, Davezac N, Dos Santos A, Perretti M, Fajac A, Sermet-Gaudelus I, Renouil M, Lesure JF, Halgand F, Laprevote O, Edelman A: Down-regulation of the anti-inflammatory protein annexin $\mathrm{Al}$ in cystic fibrosis knock-out mice and patients. Mol Cell Proteomics 2005, 4(10): 1591-|60I.

40. Saadane A, Soltys J, Berger M: Role of IL-10 deficiency in excessive nuclear factor-kappaB activation and lung inflammation in cystic fibrosis transmembrane conductance regulator knockout mice. J Allergy Clin Immunol 2005, I I 5(2):405-4I I.

41. Guilbault C, Novak JP, Martin P, Boghdady ML, Saeed Z, Guiot MC, Hudson T], Radzioch D: Distinct pattern of lung gene expression in the Cftr-KO mice developing spontaneous lung disease compared to their littermate controls. Physiol Genomics 2006.

42. Kent G, Ackerley C: Personal communication. 2003

43. Tirkos S, Chung C, Fang I, Kent G, Rozmahel R: Investigation of SIO0A8 as a modifier of lung disease in CF mice. Pediatr Pulmonol 200I, 32(S22):A299.

44. Nacken W, Roth J, Sorg C. Kerkhoff C. SI00A9/S I 00A8: Myeloid representatives of the $S 100$ protein family as prominent players in innate immunity. Microsc Res Tech 2003, 60(6):569-580.

45. Passey RJ, Xu K, Hume DA, Geczy CL: SIO0A8: emerging functions and regulation. J Leukoc Biol 1999, 66(4):549-556.

46. Ryckman C, Vandal K, Rouleau P, Talbot M, Tessier PA: Proinflammatory activities of S100: proteins SIO0A8, SIO0A9, and SI00A8/A9 induce neutrophil chemotaxis and adhesion. J Immunol 2003, I 70(6):3233-3242.

47. Roth J, Vogl T, Sorg C, Sunderkotter C: Phagocyte-specific S100 proteins: a novel group of proinflammatory molecules. Trends Immunol 2003, 24(4): I55-158.

48. Thorey IS, Roth J, Regenbogen J, Halle JP, Bittner M, Vogl T, Kaesler S, Bugnon P, Reitmaier B, Durka S, Graf A, Wockner M, Rieger N, Konstantinow A, Wolf E, Goppelt A, Werner S: The Ca2+-binding proteins SIOOA8 and SIOOA9 are encoded by novel injuryregulated genes. J Biol Chem 200I, 276(38):358I 8-35825.

49. Yui S, Nakatani Y, Mikami M: Calprotectin (SI O0A8/S I 00A9), an inflammatory protein complex from neutrophils with a broad apoptosis-inducing activity. Biol Pharm Bull 2003, 26(6):753-760.

50. Foell D, Frosch M, Sorg C, Roth J: Phagocyte-specific calciumbinding S100 proteins as clinical laboratory markers of inflammation. Clin Chim Acta 2004, 344(I-2):37-5I.

5I. Striz I, Trebichavsky I: Calprotectin - a pleiotropic molecule in acute and chronic inflammation. Physiol Res 2004, 53(3):245-253.

52. Haston CK, Tsui LC: Loci of intestinal distress in cystic fibrosis knockout mice. Physiol Genomics 2003, I 2(2):79-84

53. Haston CK, Corey M, Tsui LC: Mapping of genetic factors influencing the weight of cystic fibrosis knockout mice. Mamm Genome 2002, I3(II):6I4-618

54. Kent G, Oliver M, Foskett JK, Frndova H, Durie P, Forstner J, Forstner GG, Riordan JR, Percy D, Buchwald M: Phenotypic abnormalities in long-term surviving cystic fibrosis mice. Pediatr Res 1996, 40(2):233-241.

55. Miller SA, Dykes DD, Polesky HF: A simple salting out procedure for extracting DNA from human nucleated cells. Nucleic Acids Res 1988, 16(3):1215.

56. Ravasi T, Hsu K, Goyette J, Schroder K, Yang Z, Rahimi F, Miranda LP, Alewood PF, Hume DA, Geczy C: Probing the SI 00 protein family through genomic and functional analysis. Genomics 2004 84(I): $10-22$.

57. Edgeworth J, Gorman M, Bennett R, Freemont P, Hogg N: Identification of p8, 14 as a highly abundant heterodimeric calcium binding protein complex of myeloid cells. J Biol Chem I99I, 266( I 2):7706-77|3.

58. Hessian PA, Edgeworth J, Hogg N: MRP-8 and MRP-I4, two abundant $\mathrm{Ca}(2+)$-binding proteins of neutrophils and monocytes. J Leukoc Biol 1993, 53(2): 197-204.

59. Heizmann CW: The multifunctional SI 00 protein family. Methods Mol Biol 2002, 172:69-80

60. Hobbs JA, May R, Tanousis K, McNeill E, Mathies M, Gebhardt C, Henderson R, Robinson MJ, Hogg N: Myeloid cell function in MRP-I 4 (S I O0A9) null mice. Mol Cell Biol 2003, 23(7):2564-2576.

6I. Kerkhoff $C$, Klempt M, Kaever V, Sorg C: The two calcium-binding proteins, SIOOA8 and SIO0A9, are involved in the metabolism of arachidonic acid in human neutrophils. J Biol Chem 1999, 274(46):32672-32679.

62. Kerkhoff C, Sorg C, Tandon NN, Nacken W: Interaction of SI00A8/SI00A9-arachidonic acid complexes with the scavenger receptor CD36 may facilitate fatty acid uptake by endothelial cells. Biochemistry 200I, 40(I):24I-248.

63. Devery JM, King NJ, Geczy CL: Acute inflammatory activity of the $\mathrm{S} 100$ protein CP-I 0 . Activation of neutrophils in vivo and in vitro. J Immunol 1994, I 52(4): I 888-I897.

64. Graf JM, Smith CW, Mariscalco MM: Contribution of LFA-I and Mac-I to CD I8-dependent neutrophil emigration in a neonatal rabbit model. J Appl Physiol 1996, 80(6): I 984-1992.

65. Smith CW, Marlin SD, Rothlein R, Toman C, Anderson DC: Cooperative interactions of LFA-I and Mac-I with intercellular adhesion molecule- $I$ in facilitating adherence and transendothelial migration of human neutrophils in vitro. J Clin Invest 1989, 83(6):2008-2017.

66. Eue I, Pietz B, Storck J, Klempt M, Sorg C: Transendothelial migration of 27EIO+ human monocytes. Int Immunol 2000, I 2(II):1593-1604

67. Roth J, Burwinkel F, van den Bos C, Goebeler M, Vollmer E, Sorg C MRP8 and MRPI4, S-100-like proteins associated with myeloid differentiation, are translocated to plasma membrane and intermediate filaments in a calcium-dependent manner. Blood 1993, 82(6): | 875- I 883.

68. Mahnke K, Bhardwaj R, Sorg C: Heterodimers of the calciumbinding proteins MRP8 and MRP I 4 are expressed on the surface of human monocytes upon adherence to fibronectin and collagen. Relation to TNF-alpha, IL-6, and superoxide production. J Leukoc Biol 1995, 57(I):63-7I.

69. Newton RA, Hogg N: The human S100 protein MRP-I4 is a novel activator of the beta 2 integrin Mac-I on neutrophils. Immunol 1998, 160(3): I427-I435.

70. Vandal K, Rouleau P, Boivin A, Ryckman C, Talbot M, Tessier PA: Blockade of SI00A8 and SI00A9 suppresses neutrophil migration in response to lipopolysaccharide. J Immunol 2003 , I 7 I(5):2602-2609. 
7I. Steinbakk M, Naess-Andresen CF, Lingaas E, Dale I, Brandtzaeg P, Fagerhol MK: Antimicrobial actions of calcium binding leucocyte LI protein, calprotectin. Lancet 1990, 336(87 I8):763-765.

72. Sohnle PG, Collins-Lech C, Wiessner JH: Antimicrobial activity of an abundant calcium-binding protein in the cytoplasm of human neutrophils. J Infect Dis 1991, I63(I):187-192.

73. Santhanagopalan V, Hahn BL, Sohnle PG: Resistance of zinc-supplemented Candida albicans cells to the growth inhibitory effect of calprotectin. J Infect Dis 1995, I 7 I(5): I 289- I 294.

74. Brandtzaeg P, Gabrielsen TO, Dale I, Muller F, Steinbakk M, Fagerhol MK: The leucocyte protein LI (calprotectin): a putative nonspecific defence factor at epithelial surfaces. Adv Exp Med Biol 1995, 37I A:20I-206.

75. Sohnle PG, Hahn BL, Santhanagopalan V: Inhibition of Candida albicans growth by calprotectin in the absence of direct contact with the organisms. J Infect Dis 1996, I74(6):1369-1372.

76. Loomans HJ, Hahn BL, Li QQ, Phadnis SH, Sohnle PG: Histidinebased zinc-binding sequences and the antimicrobial activity of calprotectin. J Infect Dis 1998, 177(3):8|2-8|4.

77. Sohnle PG, Hunter MJ, Hahn B, Chazin WJ: Zinc-reversible antimicrobial activity of recombinant calprotectin (migration inhibitory factor-related proteins 8 and 14). J Infect Dis 2000, | 82(4): | 272- 2 275.

78. Nisapakultorn K, Ross KF, Herzberg MC: Calprotectin expression in vitro by oral epithelial cells confers resistance to infection by Porphyromonas gingivalis. Infect Immun 200I, 69(7):4242-4247.

79. Nisapakultorn K, Ross KF, Herzberg MC: Calprotectin expression inhibits bacterial binding to mucosal epithelial cells. Infect Immun 200I, 69(6):3692-3696.

80. Passey RJ, Williams E, Lichanska AM, Wells C, Hu S, Geczy CL, Little $\mathrm{MH}$, Hume DA: A null mutation in the inflammation-associated S100 protein SIO0A8 causes early resorption of the mouse embryo. J Immunol 1999, 163(4):2209-2216.

8I. Pechkovsky DV, Zalutskaya OM, Ivanov GI, Misuno NI: Calprotectin (MRP8/I 4 protein complex) release during mycobacterial infection in vitro and in vivo. FEMS Immunol Med Microbiol 2000 29(I):27-33.

82. Barthe C, Carrere J, Figarella C, Guy-Crotte O: Isolation of the "cystic fibrosis protein" from serum. Clin Chem 1989, 35(9): 1901-1905.

83. Barthe C, Figarella C, Carrere J, Guy CO: Identification of 'cystic fibrosis protein' as a complex of two calcium-binding proteins present in human cells of myeloid origin. Biochim Biophys Acta 1991, 1096(2): 175-177.

84. Roth J, Teigelkamp S, Wilke M, Grun L, Tummler B, Sorg C: Complex pattern of the myelo-monocytic differentiation antigens MRP8 and MRPI4 during chronic airway inflammation. Immunobiology 1992, I86(3-4):304-3।4.

85. Frosch M, Strey A, Vogl T, Wulffraat NM, Kuis W, Sunderkotter C, Harms E, Sorg C, Roth J: Myeloid-related proteins 8 and I4 are specifically secreted during interaction of phagocytes and activated endothelium and are useful markers for monitoring disease activity in pauciarticular-onset juvenile rheumatoid arthritis. Arthritis Rheum 2000, 43(3):628-637.

86. Brun JG, Haga HJ, Boe E, Kallay I, Lekven C, Berntzen HB, Fagerhol MK: Calprotectin in patients with rheumatoid arthritis: relation to clinical and laboratory variables of disease activity. Rheumatol 1992, 19(6):859-862.

87. Lugering N, Stoll R, Schmid KW, Kucharzik T, Stein H, Burmeister G, Sorg C, Domschke W: The myeloic related protein MRP8/I4 (27E I 0 antigen) - usefulness as a potential marker for disease activity in ulcerative colitis and putative biological function. Eur J Clin Invest 1995, 25(9):659-664

88. Manitz MP, Horst B, Seeliger S, Strey A, Skryabin BV, Gunzer M, Frings W, Schonlau F, Roth J, Sorg C, Nacken W: Loss of SI 00A9 (MRPI4) results in reduced interleukin-8-induced CDIIb surface expression, a polarized microfilament system, and diminished responsiveness to chemoattractants in vitro. Mol Cell Biol 2003, 23(3): 1034-1043.

89. Hu SP, Harrison C, Xu K, Cornish CJ, Geczy CL: Induction of the chemotactic S100 protein, CP-10, in monocyte/macrophages by lipopolysaccharide. Blood 1996, 87(9):39|9-3928.

90. Xu K, Geczy CL: IFN-gamma and TNF regulate macrophage expression of the chemotactic SI 00 protein SI 00A8. J Immunol 2000, 164(9):4916-4923.
91. Yen T, Harrison CA, Devery JM, Leong S, lismaa SE, Yoshimura T, Geczy CL: Induction of the SI 00 chemotactic protein, CP- I0, in murine microvascular endothelial cells by proinflammatory stimuli. Blood 1997, 90( I 2):48|2-482 I.
Publish with Biomed Central and every scientist can read your work free of charge

"BioMed Central will be the most significant development for disseminating the results of biomedical research in our lifetime. "

Sir Paul Nurse, Cancer Research UK

Your research papers will be:

- available free of charge to the entire biomedical community

- peer reviewed and published immediately upon acceptance

- cited in PubMed and archived on PubMed Central

- yours - you keep the copyright
BioMedcentral 